\title{
Enhanced Photovoltaic Performance of Nanostructured Hybrid Solar Cell Using Highly Oriented $\mathrm{TiO}_{2}$ Nanotubes
}

\author{
Supan Yodyingyong, ${ }^{\dagger, \dagger}$ Xiaoyuan Zhou, ${ }^{\dagger}$ Qifeng Zhang, ${ }^{\dagger}$ Darapond Triampo, ${ }^{\S}$ Junting Xi, ${ }^{\dagger}$ \\ Kwangsuk Park, Benjie Limketkai," and Guozhong Cao*, ${ }^{\dagger}$ \\ Department of Materials Science and Engineering, University of Washington, \\ Seattle, Washington 98195, United States, Institute for Innovative Learning, Mahidol University, 999 \\ Phuttamonthon 4 Road, Nakhon Pathom 73170, Thailand, Department of Chemistry, Center of Excellence for \\ Innovation in Chemistry, Faculty of Science, Mahidol University, Bangkok 10400, Thailand, and Intel Research \\ Laboratories Seattle, Seattle, Washington 98105, United States
}

Received: August 17, 2010; Revised Manuscript Received: September 21, 2010

\begin{abstract}
Highly oriented $\mathrm{TiO}_{2}$ nanotubes have been fabricated using $\mathrm{ZnO}$ nanorod template through liquid reactive deposition on the ITO substrates. The diameter and length of $\mathrm{TiO}_{2}$ nanotubes can be effectively controlled for the suitable use for a hybrid solar cell by varying the diameter and length of the $\mathrm{ZnO}$ nanorod template. A mixture of P3HT/PCBM was infiltrated into the gaps between $\mathrm{TiO}_{2}$ nanotubes to form hybrid solar cells. The open circuit voltage, short circuit current density, fill factor, and power conversion efficiency of the hybrid solar cell using highly oriented $\mathrm{TiO}_{2}$ nanotubes were $646 \mathrm{mV}, 9.95 \mathrm{~mA} \mathrm{~cm}{ }^{-2}, 51.6 \%$, and $3.32 \%$, respectively, much higher than $1.2 \%$ of hybrid solar cell based on $\mathrm{ZnO}$ nanorods tested under otherwise identical conditions and significantly higher than $0.7 \%$ of the same type hybrid solar cells reported in literature. The enhancement of the power conversion efficiency could be resulted from the highly oriented $\mathrm{TiO}_{2}$ nanotubes with smaller diameter and large specific surface area for the efficient electron transfer in hybrid solar cells.
\end{abstract}

\section{Introduction}

The widespread use of inorganic solar cells remains limited due to the high costs of fabrication. ${ }^{1}$ A lot of effort is being made to develop so-called third generation of solar cells including dye-sensitized solar cells, $\mathrm{DSCs}^{2,3}$ and organic photovoltaics, OPVs. ${ }^{4-6}$ OPVs or polymer-based photovoltaic devices can be processed from solution and have become a promising low cost alternative to traditional inorganic solar cell. $^{7-10}$ The key of the polymer solar cells is the bulk heterojunction, which is a blend of electron-donating semiconducting polymers and electron-withdrawing fullerides. This bulk heterojunction morphology enhances the interfacial area, where the photogenerated excitons, electron-hole pairs, are dissociated into charge carriers, and enables holes and electrons to be transported and collected. The power conversion efficiency (PCE) of the bulk heterojunction polymer solar cells which certified by the National Renewable Energy Laboratory (NREL) of up to $8.13 \%$ have been recently reported by Solarmer Energy, Inc. ${ }^{11}$ However, polymer-based solar cells still suffer from low efficiencies and the limited lifetime as compared to silicon-based solar cell. ${ }^{1}$ The limited efficiency of the bulk heterojunction polymer solar cell is due to the lower charge mobility in polymer, ${ }^{12}$ the short exciton diffusion length, which can only diffuse around $20 \mathrm{~nm},{ }^{13}$ the charge trapping in the conducting pathways of fullerides and polymer to the electrodes, ${ }^{14}$ and the mismatch of the absorption spectrum of the active layer and the solar emission. ${ }^{15,16}$ To address the intrinsic limitations of polymer solar cells, new strategies have been investigated such

\footnotetext{
* To whom correspondence should be addressed. E-mail: gzcao@ u.washington.edu.

University of Washington.

* Institute for Innovative Learning, Mahidol University.

${ }^{\S}$ Department of Chemistry, Mahidol University.

"Intel Research Laboratories Seattle.
}

as the development of new polymers with a low bandgap for better match absorption of the solar spectrum, ${ }^{17}$ and a hybrid organic/inorganic solar cells (hybrid solar cells), which are composed of an organic donor material and an $n$-type inorganic semiconductor. ${ }^{18-23}$ These hybrid solar cells have the potential to combine the properties of physical stability and high charge mobility of inorganic materials and the potential of easy control of the active layer structure and interface morphology.

The hybrid solar cells using a vertically oriented $\mathrm{TiO}_{2}$ nanotube or nanorod arrays filled with the blend of P3HT and PCBM have been investigated, ${ }^{23-28}$ which have the advantages of both the bulk heterojunction and ordered architectures. The bulk heterojunction morphology provides the sufficient interfacial area for the separation of photogenerated excitons. The ordered architectures help to reduce the electron recombination and function as the direct pathway for fast electron transport to the charge collecting electrode. In addition, when a blend of P3HT and PCBM deposited on the vertically aligned $\mathrm{TiO}_{2}$ nanotubes or nanorods, a double heterojunction structure is formed. ${ }^{23,28,29}$ This help improved the power conversion efficiency by providing electron pathways from both $\mathrm{TiO}_{2} / \mathrm{PCBM}$ interface and $\mathrm{TiO}_{2} / \mathrm{P} 3 \mathrm{HT}$ interface.

Oriented or ordered $\mathrm{TiO}_{2}$ nanotubes can be readily prepared by anodizing titanium foils in an acidic electrolyte. Although anodization of Ti film has several advantages and the hybrid solar cells achieved a high power conversion efficiency of $4.7 \%,{ }^{28}$ a dense array, precise control of the nanotube configuration and a high throughput process cannot be guaranteed, and $\mathrm{TiO}_{2}$ nanotube, fabricated by anodization of titanium foils, is difficult to use in the micro- and nanodevice applications. ${ }^{30}$ More recently, Rattanavoravipa et al. ${ }^{31}$ reported a one-step templating method to prepare highly aligned $\mathrm{TiO}_{2}$ nanowire arrays (100-150 $\mathrm{nm}$ in diameter and $1 \mu \mathrm{m}$ long), which uses $\mathrm{ZnO}$ nanorod obtained from aqueous solution route as a 
template. However, for the application of hybrid solar cell, these $\mathrm{TiO}_{2}$ nanostructures are either too densely populated, which would prevent the effective infiltration of polymer solution, or their diameters are too large, which limit the specific surface area, leading to less efficient charge separation, and a power conversion efficiency of $0.7 \%$ has been achieved. ${ }^{31}$

In this work, a simple fabrication method was employed for the growth of highly oriented $\mathrm{TiO}_{2}$ nanotubes on indium-doped tin oxide (ITO) substrates by using $\mathrm{ZnO}$ nanorods as templates, which were formed by an aqueous solution route. The diameter and the length of $\mathrm{TiO}_{2}$ nanotubes were carefully controlled for being used in the hybrid solar cell by varying the diameter and length of $\mathrm{ZnO}$ nanorod template. It was found that the hybrid solar cell based on these $\mathrm{TiO}_{2}$ nanotubes infiltrated with P3HT and PCBM showed an enhanced power conversion efficiency of $3.32 \%$, as compared to $0.7 \%$ reported in literature. ${ }^{31}$

\section{Experimental Details}

Synthesis of $\mathrm{TiO}_{2}$ Nanotubes. The deposition was conducted via a three-step procedure. (1) Seed layers were first grown to block the injection of holes into ITO electrode. ITO substrates were cleaned by acetone/ethanol sonication. These freshly cleaned ITO glasses were used to deposit a thin layer of $\mathrm{TiO}_{2}$ of thickness $\sim 30 \mathrm{~nm}$ by immersing the substrate in a solution containing $0.1 \mathrm{M}\left(\mathrm{NH}_{4}\right)_{2} \mathrm{TiF}_{6}$ and $0.2 \mathrm{M} \mathrm{H}_{3} \mathrm{BO}_{3}$ for $30 \mathrm{~min}$ at $25{ }^{\circ} \mathrm{C}$. The substrates were then spin coated by $0.60 \mathrm{~mol} \mathrm{~L}^{-1}$ of $\mathrm{Zn}\left(\mathrm{CH}_{3} \mathrm{COO}\right)_{2} \cdot 2 \mathrm{H}_{2} \mathrm{O}$ in a 2-methoxyethanol/monoethanolamine to form $\sim 50 \mathrm{~nm}$ thick seed layer of $\mathrm{ZnO}$, followed by heat treatment at $300{ }^{\circ} \mathrm{C}$ for $10 \mathrm{~min}$ to obtain dense and transparent seed layers. (2) $\mathrm{ZnO}$ template growing. The seeded substrates were placed in an aqueous solution containing 0.015 $\mathrm{M} \mathrm{Zn}\left(\mathrm{NO}_{3}\right)_{2}$ and $0.015 \mathrm{M}$ hexamethylenetetramine at $95{ }^{\circ} \mathrm{C}$ for $2 \mathrm{~h}$. Subsequently, the resultant films were thoroughly rinsed with deionized water (DI) to remove any residual salt or amino complex and dried with compressed air. (3) $\mathrm{TiO}_{2}$ nanotube forming. The synthesized $\mathrm{ZnO}$ nanorod arrays on ITO were immersed in aqueous solution consisting of $0.075 \mathrm{M}\left(\mathrm{NH}_{4}\right)_{2} \mathrm{TiF}_{6}$ and $0.2 \mathrm{M} \mathrm{H}_{3} \mathrm{BO}_{3}$ at room temperature for $1.5 \mathrm{~h}$. The resulting $\mathrm{TiO}_{2}$ nanotubes were then dipped in a $0.5 \mathrm{M} \mathrm{H}_{3} \mathrm{BO}_{3}$ solution for $1 \mathrm{~h}$ to remove any residual $\mathrm{ZnO}$. The products were then rinsed with DI water and calcined in air at $400{ }^{\circ} \mathrm{C}$ for $1 \mathrm{~h}$. Crystallographic characterizations of the samples were performed in a Bruker D8 Focus X-ray diffractometer. The surface morphology and the fracture cross section of the specimens were obtained by scanning electron microscope (SEM, Philips, JEOL JSM7000) with an energy-dispersion X-ray analyzer.

Device Fabrication and Characterization. The chlorodebenzene solution containing $20 \mathrm{mg} \mathrm{mL}^{-1}$ P3HT (Reike Metal, Sepiolid P100) and $16 \mathrm{mg} \mathrm{mL}^{-1}$ PCBM (American Dye Source Inc. ADS61BFB) was stirred inside the glovebox for overnight at $60{ }^{\circ} \mathrm{C}$ and then spin coated at $1000 \mathrm{rpm}$ onto the $\mathrm{TiO}_{2}$ nanotube covered substrates, which were first air plasma treated for $15 \mathrm{~min}$. The samples were then placed on a hot plate at 150 ${ }^{\circ} \mathrm{C}$ for 15 min to help self-organization of $\mathrm{P} 3 \mathrm{HT},{ }^{32}$ driving away residual water and assisting the polymer infiltration into the $\mathrm{TiO}_{2}$ nanotube arrays. ${ }^{28} \mathrm{~A}$ hole-transport layer of poly(3,4-ethylenedioxylene thiophene)-poly(styrene sulfonic acid) (PEDOT-PSS, Clevios P VP Al 4083) was subsequently spin-coated with a thickness of $\sim 50 \mathrm{~nm}$ outside of the glovebox and filtered through a $0.45 \mu \mathrm{m}$ filter. The films were baked at $120^{\circ} \mathrm{C}$ for $10 \mathrm{~min}$ and then the devices were transferred into a deposition chamber inside the glovebox to deposit a $100 \mathrm{~nm}$ of $\mathrm{Ag}$, which thermally evaporated under a vacuum of $2 \times 10^{-6}$ Torr. The $J-V$ characteristics of solar cell were tested in air using a

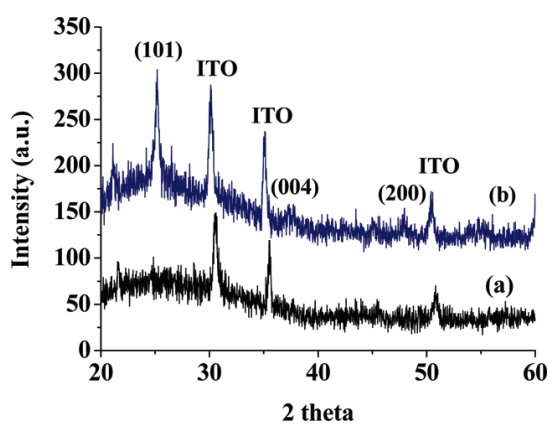

Figure 1. XRD patterns of the $\mathrm{TiO}_{2}$ nanotube films before (a) and after (b) annealed at $400{ }^{\circ} \mathrm{C}$.

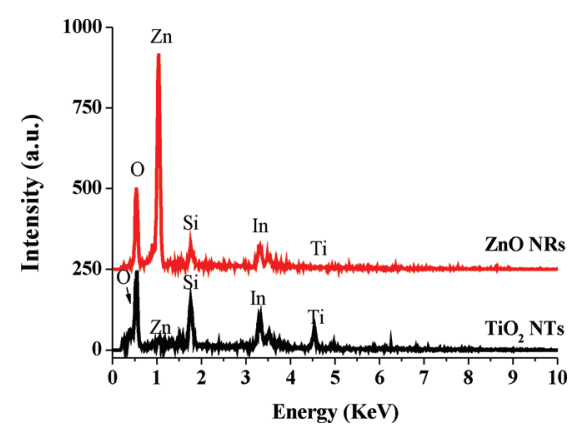

Figure 2. EDX spectra of $\mathrm{ZnO}$ nanorod ( $\mathrm{ZnO}$ NRs) arrays and $\mathrm{TiO}_{2}$ nanotube $\left(\mathrm{TiO}_{2} \mathrm{NTs}\right)$ arrays.

Keithley 2400 source measurement unit, and an Oriel Xenon lamp (450 W) coupled with an AM1.5 filter. A calibrated silicon reference solar cell certificated by the NREL was used to confirm the measurement conditions. A light intensity of 100 $\mathrm{mW} \mathrm{cm}{ }^{-2}$ was used in all the measurements in this study.

\section{Results and Discussion}

Figure 1 shows and compares the XRD patterns of the $\mathrm{TiO}_{2}$ nanotube film before (Figure 1a) and after (Figure 1b) being annealed at $400{ }^{\circ} \mathrm{C}$ for $1 \mathrm{~h}$ in air. Before annealing, the $\mathrm{TiO}_{2}$ nanotubes were amorphous, which only demonstrates the diffraction peaks from ITO glass (JCPDS Card no. 39-1058). After annealing at $400{ }^{\circ} \mathrm{C}$ for $1 \mathrm{~h}$ in air, the $\mathrm{TiO}_{2}$ nanotubes had anatase phase (JCPDS Card no. 84-1286) and there is no diffraction peaks indicating that $\mathrm{ZnO}$ templates completely removed by the final step of wet etching. On the basis of the XRD data, the final $\mathrm{TiO}_{2}$ nanotubes were found to consist of $\sim 19.4 \mathrm{~nm}$ (Scherrer equation ${ }^{33}$ ) anatase nanocrystals.

Apart from the XRD patterns, energy dispersive X-ray (EDX) before and after the formation of $\mathrm{TiO}_{2}$ nanotubes was further used to reveal the formation of $\mathrm{TiO}_{2}$ and elimination of the $\mathrm{ZnO}$ template. Figure 2 shows the EDX spectra, where $\mathrm{Zn}$ and $\mathrm{Ti}$ contents were analyzed on the $\mathrm{ZnO}$ nanorods and $\mathrm{TiO}_{2}$ nanotubes, respectively. The absence of a peak at $\sim 1 \mathrm{keV}$, corresponding to $\mathrm{Zn}$, of the EDX spectra taken from $\mathrm{TiO}_{2}$ nanotubes indicates the removal of the $\mathrm{ZnO}$ nanorod template.

Figure 3a,b shows the top view SEM images of the $\mathrm{ZnO}$ nanorod and $\mathrm{TiO}_{2}$ nanotube film. As shown in Figure 3a, highly uniform and well-spaced arrays of $\mathrm{ZnO}$ nanorods were successfully formed with preferential growth in the $c$-axis orientation (0001). Each nanotube is about $20-30 \mathrm{~nm}$ in diameter and $\sim 150-200 \mathrm{~nm}$ in length. The structure of $\mathrm{ZnO}$ nanorods was found to be very sensitive to the processing parameters, including the precursor concentration, growth temperature, and time. The SEM images of $\mathrm{ZnO}$ nanorods prepared by varying the concentration and growth time show in Figure 4. This 


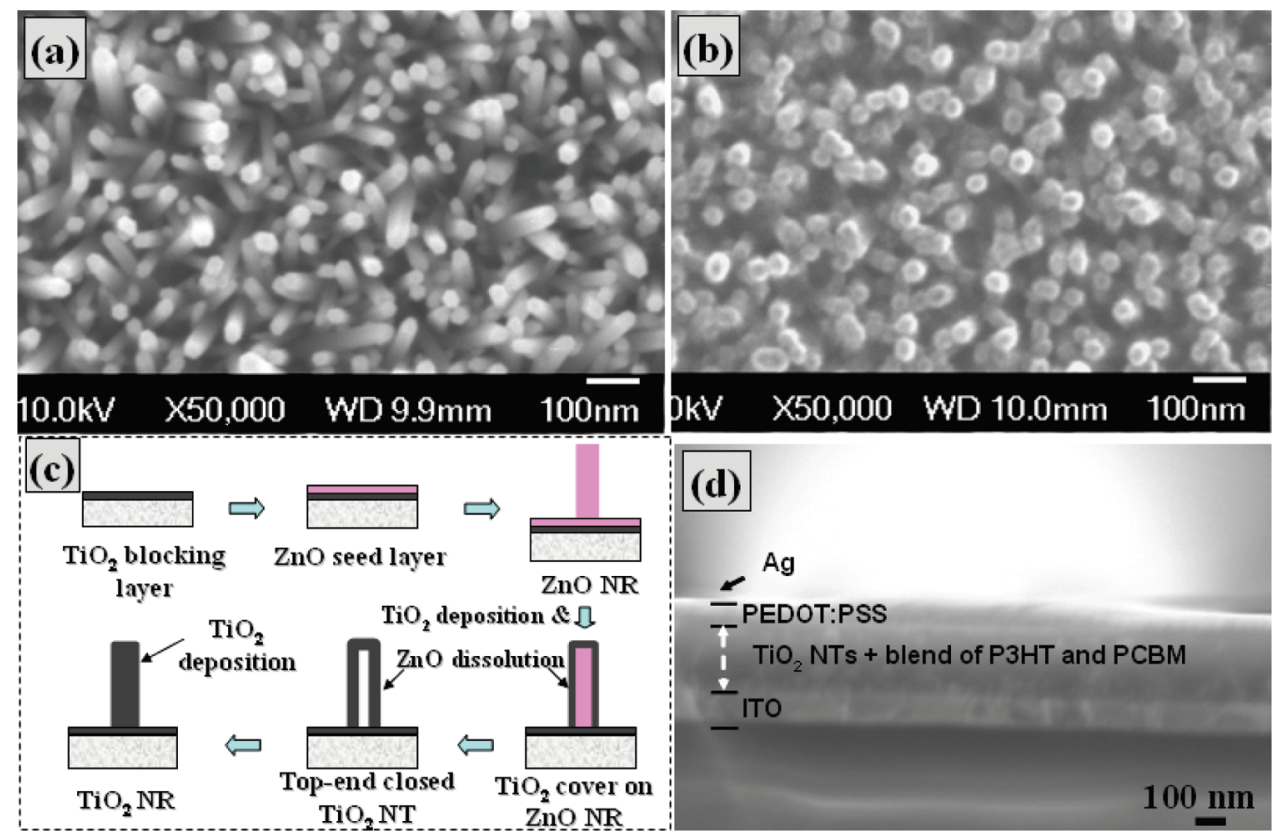

Figure 3. (a,b) The top view $\mathrm{SEM}$ images of $\mathrm{ZnO}$ nanorods and $\mathrm{TiO}_{2}$ nanotubes, respectively, (c) the schematic process of preparing $\mathrm{TiO}_{2}$ nanotubes, and (d) the cross section of hybrid solar cell photoelectrode using $\mathrm{TiO}_{2}$ nanotubes.
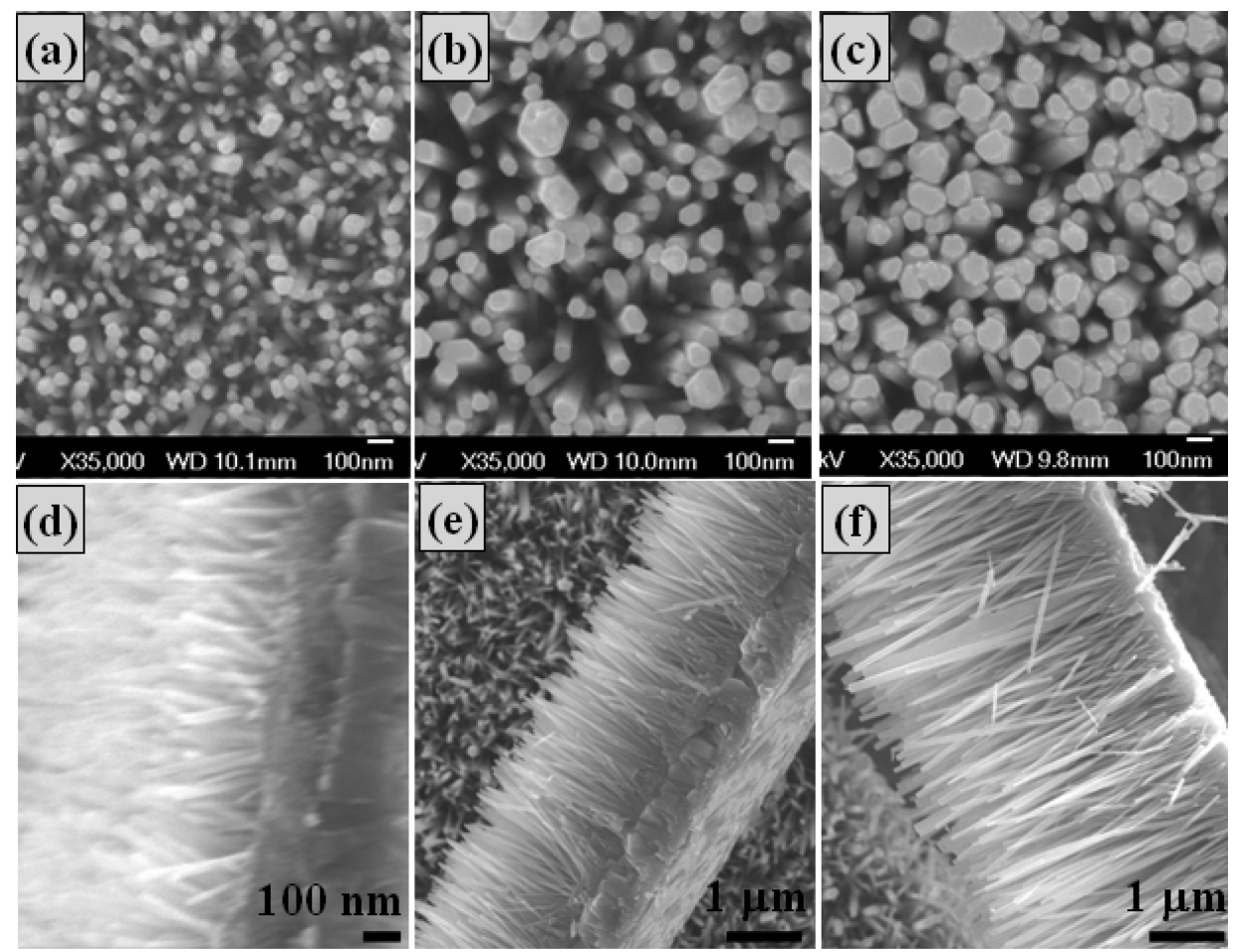

Figure 4. $(\mathrm{a}-\mathrm{c})$ The top view SEM images of $\mathrm{ZnO}$ nanorods prepared by varying the concentration of $\mathrm{Zn}\left(\mathrm{NO}_{3}\right)_{2}$ at 0.025 , 0.050 , and $0.100 \mathrm{M}$, respectively; $(\mathrm{d}-\mathrm{f})$ the cross section SEM images of $\mathrm{ZnO}$ nanorods prepared by using $0.015 \mathrm{M} \mathrm{Zn}\left(\mathrm{NO}_{3}\right)_{2}$ and varying growth time at 2 , 6 , and $12 \mathrm{~h}$, respectively.

observation is consistent with the results reported in literature. ${ }^{34}$ It was found that the length of $\mathrm{ZnO}$ nanorods can be controlled by varying the growth time in $\mathrm{ZnO}$ precursor solution. Particularly, the length of $\mathrm{ZnO}$ nanorods increases when extending the growth time, as shown in Figure $4 d-f$. Meanwhile, the diameter of nanorod is independent of the reaction time and mainly tailed by the concentration of zinc source. These $\mathrm{ZnO}$ nanorods were subsequently converted to $\mathrm{TiO}_{2}$ nanotubes via the liquid-phase deposition in an aqueous solution consisting of $\left(\mathrm{NH}_{4}\right)_{2} \mathrm{TiF}_{6}$ and $\mathrm{H}_{3} \mathrm{BO}_{3}$. It is reasonable to assume that, under optimized conditions, the $\mathrm{ZnO}$ layer could be completely removed and the $\mathrm{TiO}_{2}$ nanotubes retain the length and diameter of the $\mathrm{ZnO}$ template. The formation of $\mathrm{TiO}_{2}$ is believed to proceed via the following equation eq $1^{35,36}$

$$
\mathrm{TIF}_{6}^{2-}+2 \mathrm{H}_{2} \mathrm{O} \Leftrightarrow \mathrm{TiO}_{2}+6 \mathrm{~F}^{-}+4 \mathrm{H}^{+}
$$

This reaction can be shifted to the right by adding $\mathrm{H}_{3} \mathrm{BO}_{3}$, which reacts with $\mathrm{F}^{-}$ions and form a more stable complex ions, $\mathrm{BF}_{4}^{-}$, as outlined in eq 2 


$$
\mathrm{H}_{3} \mathrm{BO}_{3}+4 \mathrm{H}^{+}+4 \mathrm{~F}^{-} \Leftrightarrow \mathrm{BF}_{4}^{-}+\mathrm{H}_{3} \mathrm{O}^{+}+2 \mathrm{H}_{2} \mathrm{O}
$$

$\mathrm{ZnO}$ nanorods will dissolve into the solution by react with $\mathrm{H}_{3} \mathrm{O}^{+}$and this process resulted in the formation of a $\mathrm{TiO}_{2}$ nanotubes with the top-end closed

$$
\mathrm{ZnO}+2 \mathrm{H}_{3} \mathrm{O}^{+} \rightarrow \mathrm{Zn}^{2+}+3 \mathrm{H}_{2} \mathrm{O}
$$

The deposition $\mathrm{TiO}_{2}$ on the $\mathrm{ZnO}$ nanorod template and the removal of $\mathrm{ZnO}$ nanorods proceed simultaneously. ${ }^{35}$ The deposition of $\mathrm{TiO}_{2}$ continued to fill the void space within the $\mathrm{TiO}_{2}$ tubule and the $\mathrm{TiO}_{2}$ nanorod could finally be obtained, when the deposition time is sufficiently long. The resultant $\mathrm{TiO}_{2}$ nanotubes were further immersed in $\mathrm{a}_{3} \mathrm{BO}_{3}$ solution to ensure the complete removal of any residual $\mathrm{ZnO}$. The $\mathrm{pH}$ of the solution is very sensitive to the dissolution of $\mathrm{ZnO}$ nanorods. The decrease in $\mathrm{pH}$ value of the solution accelerates the dissolution of $\mathrm{ZnO}$ nanorods and will result in a lower array density of $\mathrm{TiO}_{2}$ nanotubes. ${ }^{36}$

As indicated in Figure 3b, it is observed that the diameter of $\mathrm{TiO}_{2}$ nanotubes is in the range of $\sim 20-35 \mathrm{~nm}$, which provides a large specific surface area. It should be noted that although the SEM topography shows the nanotube morphology, it is possible that the lower part (close to substrate) of the $\mathrm{TiO}_{2}$ nanotubes is filled up to form nanorods. The length of $\mathrm{TiO}_{2}$ nanotubes was controlled to be typically $150-200 \mathrm{~nm}$ for an optimal hybrid photovoltaic device performance as there is a trade-off between the distance that charge carriers need to travel to reach respective collection layer and the maximized light absorption. ${ }^{20}$ In addition, it is noticed that the $\mathrm{TiO}_{2}$ nanotube film possessed a very porous structure, that is, the nanotubes are well separated from one another, which allows the efficient infiltration of polymer solution. Figure $3 \mathrm{c}$ shows the schematic process involving the growth of barrier $\mathrm{TiO}_{2}$ layer, the $\mathrm{ZnO}$ seed layer, $\mathrm{ZnO}$ nanorods, and the deposition of $\mathrm{TiO}_{2}$ nanotubes and simultaneous $\mathrm{ZnO}$ dissolution.

Since the work function of ITO $(4.5-4.7 \mathrm{eV})$ is intermediate between the work function of HOMO and LUMO of P3HT, ITO can collect either electrons or holes. The compact $\mathrm{TiO}_{2}$ layer at the bottom of the nanotubes will function as a holeblocking layer to prevent the holes from reaching to the transparent conductive ITO substrates. ${ }^{37}$ Figure $3 \mathrm{~d}$ shows the cross-section image of $\mathrm{TiO}_{2}$ nanotubes hybrid solar cell: Ag/ PEDOT-PSS/blend of P3HT-PCBM/TiO 2 NTs/ITO.

Figure 5 shows the current density-voltage curves of the hybrid solar cells based on the $\mathrm{TiO}_{2}$ nanotubes infiltrated with a blend of P3HT and PCBM. For a better comparative study, the hybrid solar cell using $\mathrm{ZnO}$ nanorods was prepared under identical processes. The values of short-circuit current density $\left(J_{\text {sc }}\right)$, open-circuit voltage $\left(V_{\text {oc }}\right)$, fill factor $(\mathrm{FF})$, and overall power conversion efficiency $(\eta)$ are summarized in Table 1. One approach to improve the performance of hybrid solar cell is to manipulate the dimensions of $\mathrm{TiO}_{2}$ nanotubes, which is determined by the $\mathrm{ZnO}$ nanorod template. It was found that the typical maximum efficiency was obtained when growing $\mathrm{TiO}_{2}$ nanotubes with about $25-35 \mathrm{~nm}$ in diameter and $\sim 150-200$ $\mathrm{nm}$ in length. With too short and/or too small $\mathrm{TiO}_{2}$ nanotubes, the cells showed much lower performance and vice versa. As demonstrated in Figure 5, the highest performed hybrid solar cells was achieved with $V_{\mathrm{oc}}=646 \mathrm{mV}, J_{\mathrm{sc}}=9.96 \mathrm{~mA} \mathrm{~cm}^{-2}$, $\mathrm{FF}=51.6 \%, \mathrm{PCE}=3.32 \%$ for the $\mathrm{TiO}_{2}$ nanotubes annealed at $400{ }^{\circ} \mathrm{C}$ in conjunction with P3HT/PCBM. The PCE of $3.32 \%$

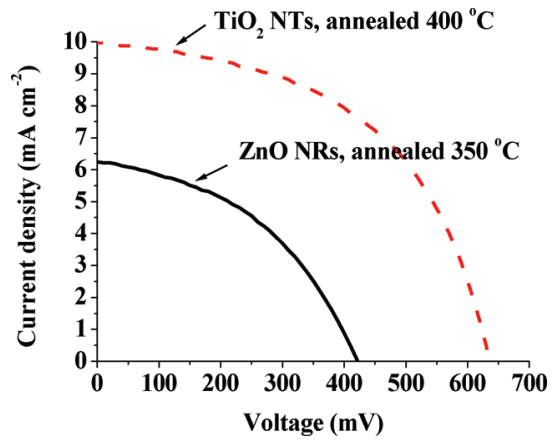

Figure 5. The current density-voltage curves of the hybrid solar cells of the $\mathrm{ZnO}$ nanorods and $\mathrm{TiO}_{2}$ nanotubes infiltrated with a blend of $\mathrm{P} 3 \mathrm{HT}$ and PCBM.

TABLE 1: Performances of the Solar Cells with the Electrode Made of $\mathrm{ZnO}$ Nanorods and $\mathrm{TiO}_{2}$ Nanotubes

\begin{tabular}{lcccc}
\hline \multicolumn{1}{c}{ samples } & $V_{\mathrm{oc}}(\mathrm{mV})$ & $J_{\mathrm{sc}}\left(\mathrm{mA} \mathrm{cm}^{-2}\right)$ & $\mathrm{FF}(\%)$ & $\eta(\%)$ \\
\hline $\begin{array}{l}\mathrm{ZnO} \text { nanorods, annealed } \\
350{ }^{\circ} \mathrm{C} \text { for } 1 \mathrm{~h}\end{array}$ & 432 & 6.28 & 43.76 & 1.19 \\
$\mathrm{TiO}_{2}$ nanotubes, & 646 & 9.95 & 51.60 & 3.32 \\
$\quad \begin{array}{l}\text { annealed } 400{ }^{\circ} \mathrm{C} \\
\text { for } 1 \mathrm{~h}\end{array}$ & & & &
\end{tabular}

achieved in this work is significantly higher than $0.7 \%$ of the same type structured hybrid solar cells reported in literature. ${ }^{31}$

Charge separation in our hybrid solar cell occurs both at the interface between P3HT and PCBM and the interface between P3HT and $\mathrm{TiO}_{2}$, a double heterojunction structure as shown in Figure 6. $\mathrm{TiO}_{2}$ nanotubes help to reduce the electron recombination and function as the direct pathway for fast electron transport to the charge collecting electrode, promising better power conversion efficiency.

The barrier layer of $\mathrm{TiO}_{2}$ at the bottom keeps the holes from touching the ITO substrates so as to increase the charge collection. As a result, the short circuit current density and open circuit voltage were remarkably enhanced. On the other hand, the hybrid solar cells based on $\mathrm{ZnO}$ nanorod/P3HT/PCBM exhibited $V_{\text {oc }}$ of $432 \mathrm{mV}, J_{\text {sc }}$ of $6.28 \mathrm{~mA} \mathrm{~cm}{ }^{-2}$, FF of $43.76 \%$, PCE of $1.19 \%$, respectively, which are comparable to $1.16 \%$ reported by Rattanavoravipa et al. ${ }^{38}$ Obviously, the $V_{\text {oc }}, J_{\text {sc, }}$ and $\mathrm{FF}$ of the dye-sensitized solar cell using $\mathrm{ZnO}$ nanorods are significantly lower than that of $\mathrm{TiO}_{2}$ nanotubes.

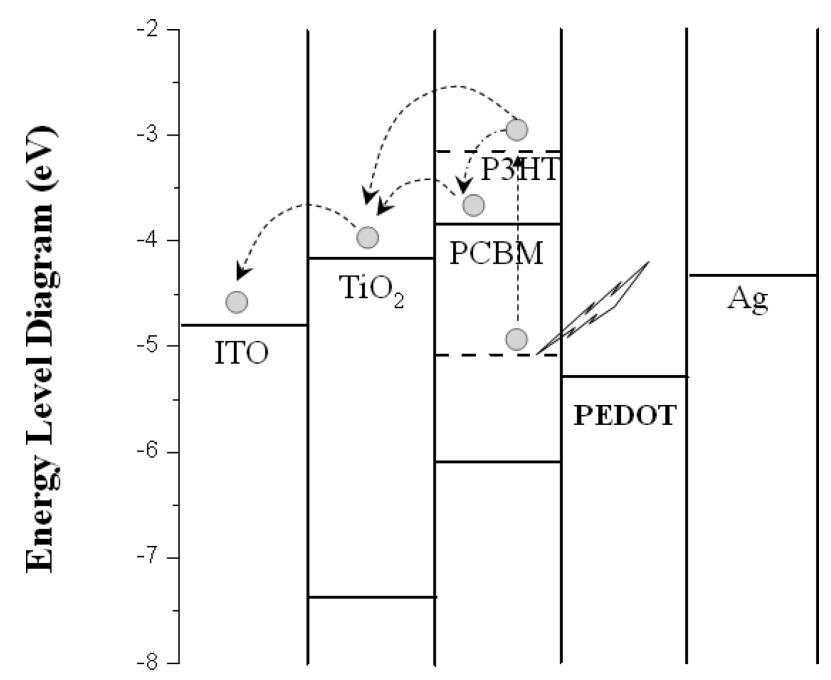

Figure 6. Schematic representation energy diagram of double heterojunction photovotaic device, ITO/TiO 2 /blend P3HT-PCBM/PEDOT/ Ag. 
It should be noted that the enhanced power conversion efficiency in this hybrid solar cells could be attributed to (1) the suitable oriented $\mathrm{TiO}_{2}$ nanotubes for the hybrid solar cell, exciton diffusion length, and (2) the oriented $\mathrm{TiO}_{2}$ nanotubes reduced the electron recombination by provided a direct pathway for fast electron transport to the charge collecting electrode. In addition, the further improved the PCE could be with the consideration of the following factors: (1) ideal $\mathrm{TiO}_{2}$ nanotubes grown perpendicular to the ITO substrates via manipulating the densities of $\mathrm{TiO}_{2}$ nanotube, and (2) interface modification and better infiltration of polymer into $\mathrm{TiO}_{2}$ nanotubes ${ }^{39}$ to improve charge separation and reduce electron recombination by tuning the polymer blend concentration, the ratio of P3HT to PCBM, spin-coat process, and polymer annealing treatment. ${ }^{40}$

\section{Conclusions}

High-power conversion efficiency in solid-state inorganicorganic solar cells that dense $\mathrm{TiO}_{2}$ nanotubes filled with a blend of P3HT/PCBM as the active layer has been demonstrated. The presence of $\mathrm{P} 3 \mathrm{HT}-\mathrm{TiO}_{2}$ heterojunction provides an additional interface as compared to conventional polymer-based photovoltaics. The resulting solar cells showed a short-circuit current density of $9.95 \mathrm{~mA} \mathrm{~cm}^{-2}$, open circuit voltage of $646 \mathrm{mV}$, and a fill factor of $51.6 \%$, leading to a power conversion efficiency of $3.32 \%$, much higher than $0.7 \%$ reported in literature. Such an enhancement in power conversion efficiency is attributed to smaller diameter of $\mathrm{TiO}_{2}$ nanotubes with a high density, yet well spaced for efficient penetration of polymer solution. Further improvement in device performance can be achieved by growing vertically oriented $\mathrm{TiO}_{2}$ nanotube array and/or by organic/ inorganic interface modification.

Acknowledgment. This work has been supported by the Institute for the Promotion of Teaching Science and Technology (IPST), the Center of Excellence for Innovation in Chemistry (PERCH-CIC), the Commission on Higher Education, Ministry of Education, a Mahidol University Research Grant, the Thailand Center of Excellence in Physics (ThEP), the U.S. Department of Energy, Division of Materials and Engineering under Award No. DE-FG02-07ER46467 (Q.F.Z.), National Science Foundation (DMR 1035196), the University of Washington TGIF grant, the Washington Research Foundation, and the Intel Corporation.

\section{References and Notes}

(1) Huynh, W. U.; Dittmer, J. J.; Alivisatos, A. P. Science 2002, 295, 2425.

(2) Zhang, Q. F.; Dandeneau, C. S.; Zhou, X. Y.; Cao, G. Z. Adv. Mater. 2009, 21, 4087.

(3) Yodyingyong, S.; Zhang, Q. F.; Park, K.; Dandeneau, C. S.; Zhou, X. Y.; Triampo, D.; Cao, G. Z. Appl. Phys. Lett. 2010, 96, 073115. 20,36

(4) Helgesen, M.; Sondergaard, R.; Krebs, F. C. J. Mater. Chem. 2010, 1324 .

(5) Günes, S.; Neugebauer, H.; Sariciftci, N. S. Chem. Rev. 2007, 107,

(6) Cheng, Y. J.; Yang, S. H.; Hsu, C. S. Chem. Rev. 2009, 109, 5868.
(7) Snaith, H. J.; Moule, A. J.; Klein, C.; Meerholz, K.; Friend, R. H.; Grätzel, M. Nano Lett. 2007, 7, 3372. 695.

(8) Po, R.; Maggini, M.; Camaioni, N. J. Phys. Chem. C 2009, 114,

(9) Lewis, N. S. Science 2007, 315, 798.

(10) Cai, W.; Gong, X.; Cao, Y. Sol. Energy Mater. Sol. Cells 2010 , 94, 114.

(11) Solarmer Energy, Inc. http://www.solarmer.com/ (accessed September 14, 2010).

(12) Shao, S.; Liu, F.; Xie, Z.; Wang, L. J. Phys. Chem. C 2010, 114, 9161

(13) Scully, S. R.; McGehee, M. D. J. Appl. Phys. 2006, 100, 034907.

(14) Yang, F.; Shtein, M.; Forrest, S. R. Nat. Mater. 2005, 4, 37.

(15) Wienk, M. M.; Turbiez, M. G. R.; Struijk, M. P.; Fonrodona, M.; Janssen, R. A. J. Appl. Phys. Lett. 2006, 88, 153511.

(16) Markus, K.; Hans-Joachim, E.; Gilles, D.; Markus, C. S.; Christoph, J. B.; Pavel, S.; Claudia, N. H. Adv. Funct. Mater 2010, 20, 338.

(17) Yongye, L.; Zheng, X.; Jiangbin, X.; Szu-Ting, T.; Yue, W.; Gang, L.; Claire, R.; Luping, Y. Adv. Mater. 2010, 22, 1.

(18) Mor, G. K.; Kim, S.; Paulose, M.; Varghese, O. K.; Shankar, K.; Basham, J.; Grimes, C. A. Nano Lett. 2009, 9, 4250.

(19) Briseno, A. L.; Holcombe, T. W.; Boukai, A. I.; Garnett, E. C.; Shelton, S. W.; Frechet, J. J. M.; Yang, P. Nano Lett. 2009, 10, 334.

(20) Greene, L. E.; Law, M.; Yuhas, B. D.; Yang, P. J. Phys. Chem. C 2007, 111, 18451.

(21) Ravirajan, P.; Peiro, A. M.; Nazeeruddin, M. K.; Grätzel, M.; Bradley, D. D. C.; Durrant, J. R.; Nelson, J. J. Phys. Chem. B 2006, 110, 7635

(22) Zhu, R.; Jiang, C. Y.; Liu, B.; Ramakrishna, S. Adv. Mater. 2009 , 21, 994 .

(23) Shankar, K.; Mor, G. K.; Prakasam, H. E.; Varghese, O. K.; Grimes, C. A. Langmuir 2007, 23, 12445.

(24) Yu, B. Y.; Tsai, A.; Tsai, S. P.; Wong, K. T.; Yang, Y.; Chu, C. C.; Shyue, J. J. Nanotechnology 2008, 19, 255202.

(25) Chen, C.; Wang, M.; Wang, K. J. Phys. Chem. C 2009, 113, 1624.

(26) Otsuka, Y.; Okamoto, Y.; Akiyama, H. Y.; Umekita, K.; Tachibana,

Y.; Kuwabata, S. J. Phys. Chem. C 2008, 112, 4767.

(27) Shankar, K.; Mor, G. K.; Prakasam, H. E.; Varghese, O. K.; Grimes, C. A. Langmuir 2008, 24, 14321.

(28) Mor, G. K.; Shankar, K.; Paulose, M.; Varghese, O. K.; Grimes, C. A. Appl. Phys. Lett. 2007, 91, 152111.

(29) Shankar, K.; Mor, G. K.; Paulose, M.; Varghese, O. K.; Grimes, C. A. J. Non-Cryst. Sol. 2008, 354, 2767.

(30) Yang, D. J.; Kim, H. G.; Cho, S. J.; Choi, W. Y. Mater. Lett. 2008, 62,775 .

(31) Rattanavoravipa, T.; Sagawa, T.; Yoshikawa, S. Sol. Energy Mater. Sol. Cells 2008, 92, 1445.

(32) Park, J. H.; Kim, J. S.; Lee, J. H.; Lee, W. H.; Cho, K. J. Phys. Chem. C 2009, 113, 17579.

(33) Fujihara, K.; Kumar, A.; Jose, R.; Ramakrishna, S. Nanotechnology 2007, 18, 365709.

(34) Qiu, J. J.; Yu, W. D.; Gao, X. D.; Li, X. M. Nanotechnology 2006, 17,4695 .

(35) Xu, C.; Shin, P. H.; Cao, L.; Wu, J.; Gao, D. Chem. Mater. 2009, $22,143$.

(36) Lee, J. H.; Leu, I. C.; Hsu, M. C.; Chung, Y. W.; Hon, M. H. J. Phys. Chem. B 2005, 109, 13056.

(37) Boucle, J.; Ravirajan, P.; Nelson, J. J. Mater. Chem. 2007, 17, 3141.

(38) Rattanavoravipa, T.; Chareonsirithavorn, P.; Sagawa, T.; Yoshikawa, S. Solid-State Electron. 2009, 53, 176.

(39) Tepavcevic, S.; Darling, S. B.; Dimitrijevic, N. M.; Rajh, T.; Sibener, S. J. Small 2009, 5, 1776.

(40) Ballantyne, A. M.; Ferenczi, T. A. M.; Campoy-Quiles, M.; Clarke, T. M.; Maurano, A.; Wong, K. H.; Zhang, W.; Stingelin-Stutzmann, N.; Kim, J. S.; Bradley, D. D. C.; Durrant, J. R.; McCulloch, I.; Heeney, M.; Nelson, J.; Tierney, S.; Duffy, W.; Mueller, C.; Smith, P. Macromolecules 2010, 43, 1169.

JP1077888 